\title{
Library Roles in American Higher Education
}

\begin{abstract}
This paper was delivered May 12, 1969, at the First U.S. Conference on Libraries and Information Science in Higher Education, held in Tokyo, Japan. We print it here because it is indicative of the American Council on Education's current interest in libraries.
\end{abstract}

B EING NeITHER a Librarian nor an information science expert, I appear as an amateur among professionals so far as the technical content of this important conference is concerned. True, during my youth I worked one summer as a stack boy in a college library, and I once contributed a minor item to the Library Quarterly. These experiences hardly warrant my coming almost 8,000 miles from Washington-even to such a delightful country as Japan-to tell leading librarians things they already know about libraries!

Regarding the interrelations between libraries and higher education, however, I can speak from a background of varied experience as a student, teacher, and administrator on more than a dozen different college and university campuses. For the past eight years I have been with the American Council on Education, an association of more than 1,500 colleges, universities, and other educational agencies; this national perspective has given me a further appreciation of the vital role that libraries play in the conservation, dissemination, and advancement of education.

As we consider the interrelations be-

Dr. Wilson is President, American Council on Education. tween libraries and educational institutions, it may be useful to review briefly the changing functions of libraries and librarians. In America, the first libraries were rather limited book collections for even more limited circles of readers. Perhaps inevitably the early librarian was thought of primarily as a guardian or human watchdog. One of his first duties was to preserve from harm the scarce and valuable commodities in his custody. Instead of trying to put books and periodicals into as many hands as possible, the librarian's main task apparently was to keep them out of the wrong hands.

An amusing account of the early role of the American librarian is to be found in The Old Librarian's Almanack, alleged to have been written in 1773 by one Jared Bean. Some of his admonitions are as follows:

Keep your Books behind stout Gratings, and in no wise let any Person come at them to take them from the Shelf except yourself.

It were better that no Person enter the Library (save the Librarian Himself) and that the Books Be kept in Safety, than that one Book be lost, or others Misplac'd. Guard well your Books,-this is always your foremost Duty. 
Question each Applicant closely. See that he be a Person of good Reputation, scholarly Habits, sober and courteous Demeanour. Any mere Trifler, a Person that would Dally with Books, or seek in them shallow Amusement, may be Dismiss'd without delay.

Our old librarian goes on to caution against admitting to the library anyone younger than twenty years, advises strong suspicions of all women, and the complete exclusion of politicians, astrologers, teachers of false knowledge, fanatic preachers, and refugees. He further counsels the true librarian to cast out and destroy all books merely frivolous and empty of serious meaning. Finally, he praises the librarian as one who "lives protected, avaricious neither of money nor of worldly fame, and happy in the goodliest of all occupations,-the pursuit of wisdom."

With the expansion of education and the growth of knowledge, the librarian emerged from his initial role as guardian of carefully culled knowledge for the select few into a second, predominant role. In this second stage he may be described as the omnivorous collector of practically anything in print. This period saw the rise of American public, college, and university libraries from the base of the subscription library.

All over the United States libraries were established as rather indiscriminate repositories of miscellaneous information. The growth was often an unplanned, mushroom development, and librarians were for the most part essentially amateur rather than professional workers. The collector-librarian was (and to some extent still is) in his heyday. Too frequently, little attention was paid to real needs, and even in college and university libraries quantities of books were gathered and housed with a cavalier disregard for the comfort, convenience, or requirements of those to be served. The number of titles steadily mounted, cataloging grew progressively more com- plex and expensive, and the omnivorous collector-librarian was as happy as a miser who gathers unto himself a large hoard.

American librarians are quite familiar with the assertion that if this tendency continues unchecked, university campuses will be as taken up with libraries as the landscape of China is with cemeteries. Several decades ago somebody pointed out that the then current rate of growth of the Yale University library would in the year 2040 result in a book collection numbering over 200,000,000 volumes, occupying 6,000 miles of shelves, and requiring 6,000 librarians merely to do the cataloging.

The present-day librarian, as you know, is neither a mere custodian of books nor an omnivorous collector of miscellaneous printed works. On the campus, he must and does work closely with subject-matter specialists in teaching and in research. If his library is modern and well-designed, it is a convenient and inviting place for students as well as for more advanced scholars and researchers to work with and enjoy books. Moreover, the confines of the library contain not only books, manuscripts, and periodicals, but also slides, films, recordings, various microforms, and the facilities for using them. With the growing emphasis on independent student learning, and the declining stress on classroom lecturing and textbook memorization, the modern college or university library is no less important than the classroom and the laboratory as a place where learning is disseminated and advanced.

All of these developments mean, of course, that a new breed of librarian is emerging to meet changed and more complex demands for services. In addition to being able to communicate effectively with advanced scholars and beginning undergraduates, he and his colleagues in the library must know a great deal about data processing technology. 
Not only must he be able to analyze and manage the knowledge system over which he presides, but also he must be able to relate it effectively to national and even international networks of information.

This international conference in Tokyo signifies very concretely the widened horizons of library leaders and their enlarged roles in contemporary society. As you look to one another for new and better ideas about how to conduct your increasingly complex enterprises, I would emphasize that institutions of higher education throughout the civilized world also look to you for ways to enhance teaching, learning, and research.

In an era of strident mass communication, it seems to me that librarians and other educators have a particular obligation to promote the wider and better use of one of man's greatest inventions, the book. I do not minimize the importance of other communications devices, including the latest gadgets of the new learning technology, but their spectacular features are likely to cause us-indeed are causing us-to overlook many of the advantages residing in the book as a superb device for human communication and understanding.

Because of the time-honored relationship between books and learning, we need to remind ourselves that the relationship is still viable. The world about us has grown so complex and the accumulated knowledge about it so vast, and often abstract, that book learning and its practitioners are essential elements to social survival. What other devices enable a wide range of thinkers of the past and the present to speak to us so readily? Despite progress in making mechanical communications devices inexpensive and portable, I still know of none that can be purchased in paper covers for less than a dollar, borrowed without cost from a library, carried in one's pocket, used anywhere without plugging in, and then be placed back on a shelf to be always ready for later use. Great teachers are not always accessible in person, but the wisdom of all the ages, including our own, is distilled for us on every conceivable subject in book form. No admission is charged for those who wish to read for enjoyment, and no station interruptions puff the virtues of cosmetics, breakfast foods, or cigarettes. Moreover, the reader as learner can set his own pace, and as enjoyer does not have to fit his taste to that of thousands or millions of other people.

Many years ago, Francis Bacon noted that reading makes the full man. Librarians and other educators need to join efforts everywhere, it seems to me, in doing all in their power to further the use of that familiar but often neglected object, the book. For those who want knowledge or inspiration, there is no handier place to get it. For the worried or weary, there is no better tranquilizer. For the bored or the adventurous, there is no easier mode of flight to other times and places. For those who want to promote a better understanding of other cultures, readily available books in translation afford inexpensive means of bringing diverse peoples into closer association with one another's ideas and aspirations.

In colleges and universities, especially, the library constitutes the keystone of teaching and learning. Paul Buck, Harvard historian and librarian, once noted that "a quality education is impossible without a quality library," and compared "the student in many college courses to a traveler abroad who keeps his nose in the guidebook and never looks at the life around him. Teaching with textbooks means offering the student body only a guidebook instead of the variations and depth of experience to be found in living books."

His book, Libraries and Universities, 
also notes that in the United States a superior library is an important element in attracting a superior faculty to an institution of higher education. Although many American collegiate libraries fall below the standards set by Dr. Buck, I certainly agree with him that "the library is the heart of education." In an era when students in many countries, including Japan and the United States, are protesting the kind of classroom instruction they are getting, I wonder why more of them do not spend more time in the library freely pursuing their own intellectual interests and less time milling about on the campus demanding pedagogical reforms.

Some of their professors may indeed be stodgy and limited in their points of view, but there is nothing limited about the range of ideas or perspectives to be had in a well-stocked library. Nowhere else on the campus-or away from it, for that matter-is there more freedom to run the whole gamut of what men of all times and places have thought and said.

Furthermore, a good library can never be accused of spoon-feeding those who use it. The student who can use the library as an intellectual resource is not a passive recipient of information and ideas obtained from lectures and textbooks. By searching out the answers to his own questions, he engages actively in self-education. A common task of teachers and librarians, therefore, is to stir the curiosity of young people and to show them how to satisfy that curiosity. In short, I believe that student activists who really want to change the world would be well-advised to "invade" the library instead of the office of the president.

I am not familiar with practices in Japan, but in the United States a good many colleges and universities do make an honest effort to acquaint beginning students with the rudimentary uses of the library. Freshmen orientation week often includes a tour of the library, with some instruction about how books are classified and shelved, what the rules and regulations are for borrowing and returning books, where different kinds of materials may be found, and so on. Further instruction may be given during the opening semester as part of one or more courses of study, such as the introductory course in English. A national survey published a few months ago indicated that such teaching is increasingly common, although American librarians agree that more is needed.

The growing vogue among many American colleges and universities for independent study for advanced students has given rise to programs that may require few, if any, regular class meetings. The student has periodic conferences with his professor-in effect, he teaches himself. In the humanities and social sciences, his most important aid to learning necessarily is the library. Independent study, to be sure, cannot be recommended as superior to all other modes of learning. It can, however, as one critique has mentioned, have a "liberating effect on the student, who becomes freer to exercise his choice of discrimination, and on the instructor, who becomes less involved in the purveyance of information and more concerned with the development of curiosity and judgment."

To make libraries more physically and intellectually inviting to their undergraduates, some of our most comprehensive universities have established separate buildings for them. There, the bookshelves are typically open to browsers, and reading rooms are often furnished with comfortable chairs and even ash trays for those who wish to smoke. For example, the Harvard University library, with its $8,000,000$ or so volumes, has adjacent to its large main building a much smaller one for undergraduates, 
with only 150,000 volumes, all readily accessible. The University of Michigan has twelve residence hall libraries, the largest offering approximately 2,500 books, 1,100 phonograph records, and 70 periodicals and newspapers. When I was at the University of Texas, we followed the Harvard example and built a library primarily for undergraduates next to the much larger main library. The response of students to our emphasis on "access and exposure," I might add, was most gratifying.

At a time when higher education in most countries is beset with the twin problems of growing numbers of "consumers" and soaring costs, perhaps we can find solutions through a better utilization of our libraries. In my country, more and more institutions are willing to grant credits to students who can pass examinations covering the subject matter of scheduled courses in which they have not been registered. It is also becoming increasingly common to give advanced standing by examinationthat is, to allow a student to take a sequential course on a higher level than that to which his completed course work would entitle him. I suggest also that colleges and universities should give more attention to the continuing education of mature persons who may not be formally classified as students. They too require aid in the process of self-education and in the use of libraries as indispensable adjuncts to the achievement of learning.

As you well know, the quality of library holdings does relate to the quality of formal education. To identify quality in advanced education and to find out what factors are associated with it, the American Council on Education made a comparative study several years ago of graduate departments in twenty-nine academic disciplines among the 106 American universities offering appreciable work on the doctoral level. In commenting on the relation between aca- demic quality and library resources, Allan M. Cartter, the author, noted:

The library is the heart of the university; no other single nonhuman factor is as closely related to the quality of graduate education. A few universities with poor library resources have achieved considerable strength in several departments, in some cases because laboratory facilities may be more important in a particular field than the library, and in other cases because the universities are located close to other great library collections such as the Library of Congress and the New York Public Library. But institutions that are strong in all areas invariably have major national libraries. The seventeen universities among the first twenty institutions in our study (omitting the three leading institutions of science or technology) had total library holdings ranging from 1.3 million to nearly 8 million volumes; the average holding was 2.7 million volumes. The bottom twenty institutions among the 106 in the survey had libraries ranging from 125,000 to one million volumes, averaging 465,000.

The monograph, entitled An Assessment of Quality in Graduate Education, goes on to point out that the size of a library does not necessarily measure its adequacy for scholarly purposes. During the study, an index was devised, accordingly, for total volumes, for volumes added, for periodicals, and for an overall library indicator. In the computation, the figure 1.00 was chosen to indicate the average number of volumes or periodicals for all universities in the survey. When this base figure was applied in each of the four comparisons, Harvard was found to have a higher index standing than any other American university, except on the periodicals index, where it was exceeded by the University of California at Berkeley.

The other top-ranking university libraries in the United States, in respective order, were at Yale, the University of California at Los Angeles, Cornell, Illinois, Stanford, Michigan, Columbia, 
and Chicago. The next nine, listed alphabetically, were those at Johns Hopkins, Minnesota, Northwestern, Ohio State, Pennsylvania, Princeton, Texas, Washington, and Wisconsin. The overall library resources index for the first group of institutions ranged from 2.44 to 5.29, and for the latter group from 1.50 to 1.99 .

This study observed that all universities having overall faculty ratings of "strong" or "distinguished" also had library resources scores above 1.4. Overall, library resources hold somewhat lesser importance to such specialized and distinguished institutions as the Massachusetts Institute of Technology and the California Institute of Technology. Even in these instances, however, a significant relationship maintains between the strength of the library and the academic standing of the institution.

Turning now from the academic scene to a broader consideration of what might be called "the power of books," I want to relate library resources more broadly to national resources. As a strong believer in the generally beneficial influence of books on human beings, I am somewhat dismayed to acknowledge for my own country the inordinate amount of time people of virtually all age groups spend watching television. In reading recently about Japan, I noted that there also more than 80 percent of the households own television sets, and that the per capita ownership of books is low. In these respects the masses of our people in both nations apparently make somewhat similar use of their leisure time.

I found encouragement elsewhere, however, in learning that both of our nations rank among the leading five publishing countries of the world. As an American with a warm feeling of friendliness toward Japan, I was pleased to observe that that nation imports more books from the United States than from any other country. Unfortunately for us Americans, there are more Japanese who read English than persons in my country who read Japanese, and thus the flow of books is not equal in both directions; I can assure you, though, that our interest in your people and your culture is growing continuously. To my way of thinking, the interchange of books and ideas, of scholars and students, is even more important than diplomacy in the furtherance of international understanding and world peace. Librarians no less than diplomats need to communicate with one another, and in so doing everyone benefits.

Furthermore, I think it could be demonstrated that there is a fairly close relationship between the prosperity and strength of a nation and the values it attaches to the kinds of knowledge found in libraries. The recent Report of the President of the Carnegie Institution of Washington, commenting on some findings by an American scholar, Derek Price, notes:

In a series of penetrating studies, he has been able to show that the contribution of the various nations of the globe to the world's store of scientific information per se, as measured by the share of the world's scientific papers in various fields annually issuing from them, is remarkably coordinate, not with their total populations, not with their own estimates of the funds which their governments expend in research and development-which may vary from less than 1 percent of their annual budgets to the high of approximately 3.5 percent of the gross national product reckoned for our own country -but, remarkably enough, with their overall national wealth. That proportion turns out to be extraordinarily uniform among all nations which are making significant contributions to the global accumulation of scientfic knowledge.

In the unremitting competition of our planet, it is crystal clear that any nation which permits its scientific resources to wither, or even to diminish, over any considerable period of time is ipso facto gravely compromising its position in the 
world. And the greatest of these resources, of course, is the human one. . .

This citation speaks only of scientific knowledge and resources, of course, but I suspect that a comparable inquiry into library resources and their utilization would yield similar findings and conclusions. Japan and the United States are both prosperous, strong nations. To maintain our prosperity and strength, however, both nations must be willing to ensure adequate support for our libraries and our educational institutions. We librarians and educators therefore have an obligation not only to render the best services we can but also to impress upon our constituents the indispensability of sufficient material support and public understanding for a continuous enlargement and improvement of these services.

In closing, let me say that mankind owes a debt of gratitude to libraries and librarians for services to the advancement of higher learning and of civilization. Although libraries already are estimable social agencies, the presence at this conference of leading Japanese and American librarians signifies a desire to improve further their efficiency and effectiveness. I would remind you that the effort to enhance the increase of knowledge and its better utilization not only strengthens nations, but also promotes the rule of reason and mutual understanding throughout the world. Far from being mere custodians of accumulated knowledge, you play vital roles in raising the quality of human life. I commend those who were responsible for organizing this conference, and wish all of you every success in carrying forward its implications. 